\title{
Parasitism Capacity of Telenomus remus Nixon (Hymenoptera: Scelionidae) on Spodoptera frugiperda (Smith) (Lepidoptera: Noctuidae) Eggs
}

\author{
Regiane Cristina Oliveira de Freitas Bueno ${ }^{1 *}$, Tatiana Rodrigues Carneiro ${ }^{2}$, Adeney de \\ Freitas Bueno $^{3}$, Dirceu Pratissoli ${ }^{4}$, Odair Aparecido Fernandes ${ }^{2}$ and Simone Silva Vieira ${ }^{5}$ \\ ${ }^{1}$ Universidade de Rio Verde; 75901-970; Rio Verde - GO - Brasil. ${ }^{2}$ Departamento de Fitossanidade; Universidade \\ Estadual Paulista; 14884-900; Jaboticabal - SP - Brasil. ${ }^{3}$ Empresa Brasileira de Pesquisa Agropecuária - Embrapa \\ Soja; Rodovia Carlos João Strass; C. P.: 231; 86001-970; Londrina - PR - Brasil. ${ }^{4}$ Departamento de Fitotecnia; \\ Centro de Ciências Agrárias; Universidade Federal do Espírito Santo; 29500-000; Alegre - ES - Brasil. \\ ${ }^{5}$ Universidade do Estado de Santa Catarina; Lages - SC - Brasil
}

\begin{abstract}
This work studied the parasitism capacity of Telenomus remus Nixon (Hymenoptera: Scelionidae) on Spodoptera frugiperda (Smith) (Hymenoptera: Scelionidae) eggs at 15, 20, 25, 28, 31, and $35^{\circ} \mathrm{C}$, aiming to use this natural enemy in biological control programs in crops where $\mathrm{S}$. frugiperda was considered pest. The parasitism during the first $24 \mathrm{~h}$ was $60.90,81.65,121.05,117.55$ and 108.55 parasited eggs per female from egg masses of approximately 150 eggs, at $15,20,25,28$ and $31^{\circ} \mathrm{C}$, respectively. Females of $\mathrm{T}$. remus reached parasitism higher than $80 \%$ at 15 , 20, 25, 28 and $31^{\circ} \mathrm{C}$ at 5, 27, 8, 2, and 2 days, respectively. At $35^{\circ} \mathrm{C}$, there was no parasitism. The highest parasitism rates occurred at 20, 25, 28 and $31^{\circ} \mathrm{C}$. T. remus female longevity varied from 15.7 to 7.7 days from 15 to $31^{\circ} \mathrm{C}$. The highest tested temperature $\left(35^{\circ} \mathrm{C}\right)$ was inappropriate for $\mathrm{T}$. remus development. At that temperature, female longevity was greatly reduced (1.7 \pm 0.02$)$ and egg viability was null. All T. remus survival curves were of type I, which showed an increase in mortality rate with time.
\end{abstract}

Key words: Eggs parasitoid, fall armyworm, biological control, Integrated Pest Management

\section{INTRODUCTION}

The fall armyworm, Spodoptera frugiperda, is considered the most important maize pest in several countries such as Brazil, Venezuela and Mexico (Cave, 2000). A large amount of money is annually spent in attempts to control this pest (Cruz, 1995). Among the control strategies, insecticide is the most used to control $S$. frugiperda outbreaks (Figueiredo et al., 1999; Morales, 2001). Among the negative effects of the use of some insecticides is the development of insecticide resistance and environmental contamination (Diez-Rodriguez and Omoto, 2001). A good alternative to circumvent these problems is the biological control implementation. This control method is an excellent alternative to avoid an abusive use of chemical control (Ferrer, 2001; Figueiredo et al. 1999). Several works have shown the high number of parasitoid species from different corn regions and also stressed the importance of these biological enemies to keep $S$.

*Author for correspondence: regianecrisoliveira@gmail.com 
frugiperda outbreaks below the economic threshold (Schwartz and Gerling, 1974; Ferrer, 2001; Figueiredo et al., 1999). Among these egg parasitoids, Telenomus remus has a great value due to its specificity. Furthermore, its efficacy on $S$. frugiperda control has been proved in different countries such as Venezuela and Mexico (Hernández, 1996; Cave, 2000; Figueiredo et al., 2002). T. remus releases are able to reach from $78 \%$ up to $100 \%$ parasitism on S. frugiperda eggs when a range from 5000 to 8000 parasitoids are realeased per hectare (Cave, 2000).

Grower`s necessities for biological control are evident around the world; however, studies are still needed and are crucial to the success of any biological control program implementation (Figueiredo et al., 1999). Studies looking into the biological parameters are key points that might lead to the success of parasitoid use to control some of the major pests (Fuentes, 1994). These parameters might be greatly influenced by the environment such as humidity, light, and mainly the temperature (Noldus, 1989). A study on the parasitism capacity of $T$. remus in regard to the temperature gives important insights to the implementation of $S$. frugiperda Integrated Pest Management programs (Bleicher and Parra, 1990; Hernández et al., 1989). Therefore, this work was carried out aiming to evaluate $T$. remus parasitism capacity on $S$. frugiperda under different temperatures $\left(15,20,25,28,31\right.$ and $\left.35^{\circ} \mathrm{C}\right)$ to acquire the required knowledge to later sucessfully use this parasitoid in biological control programs in crops where $S$. frugiperda was a pest.

\section{MATERIAL AND METHODS}

The adults of the $S$. frugiperda livestock were kept in PVC cages $(10 \mathrm{~cm}$ of diameter and $21.5 \mathrm{~cm}$ high) from where the eggs were collected. These cages had a fine meshed fabric on the top and paper on inner surfaces to facilitate egg removals. Adults were fed through a piece of cotton wetted with honeyed water (10\% honey), kept on the top of the fabric that covered the cages. This piece was changed each $72 \mathrm{~h}$ and the eggs were removed on a daily basis. Each egg mass removed was placed in a plastic cup with $5 \mathrm{~g}$ of artificial diet. These cups were properly closed and kept in a room with controlled temperature and humidity $\left(25 \pm 1^{\circ} \mathrm{C}, 70\right.$ $\pm 10 \%$ of relative humidity, and $12 \mathrm{~h} \mathrm{~L}$ :D). $S$. frugiperda larvae were grown individually to avoid the cannibalism until pupation. Pupae were separated according to sex and then new cages were set up with seven couples each. The artificial diet used was adapted from Kasten et al. (1978).

T. remus livestock was set up with the insects received from EMBRAPA Sete Lagoas, MG, livestock. S. frugiperda egg masses (approximately 150 eggs each) were glued on a square cardboard $(2 \mathrm{~cm} \times 8 \mathrm{~cm})$. Three of this squares with the eggs were placed into a glass tube ( $8 \mathrm{~cm}$ lenght and $2 \mathrm{~cm}$ diameter) with eggs previously parasited by $T$. remus. Inside these tubes, small honey drops were placed to feed the adults when emerged. These tubes were then properly closed and $T$. remus parasitism was allowed for $24 \mathrm{~h}$. The insects were kept under controlled conditions $\left(25 \pm 11^{\circ} \mathrm{C}, 70 \pm 10 \%\right.$ of relative humidity, and $12 \mathrm{~h}$ of photo phase) and new $S$. frugiperda eggs were offered to $T$. remus on a daily basis.

The experiments were carried out using the egg masses not older than $24 \mathrm{~h}$. Egg masses of approximately 150 eggs each were stuck to a rectangle cardboard $(2 \mathrm{~cm} \mathrm{x} 8 \mathrm{~cm})$. This cardboard was individually placed in a glass tube $(8 \mathrm{~cm}$ length $\mathrm{x} 2 \mathrm{~cm}$ diameter). A honey drop was placed in this glass tube prior to the parasitoid placement. Then, a newly emerged $T$. remus female (less than $24 \mathrm{~h}$ old) was placed into each tube and a total of 20 tubes (replications) were kept at different temperature $\left(15,20,25,28,31,35^{\circ} \mathrm{C}\right)$ with $70 \pm$ $10 \%$ of humidity and $12 \mathrm{~h}$ photo phase. The $S$. frugiperda eggs were daily replaced up to $T$. remus death. The parasitized eggs that were removed were also kept at each specific temperature accordingly to the treatment. The parameters evaluated were: daily number of parasitized eggs; total number of parasitized eggs, total parasitism (\%), adult longevity. The results were analyzed using ANOVA and means were compared by Tukey's test $(\mathrm{P}=0.05)$. The distribution model of Weibull was used to estimate the mean longevity of the $T$. remus population using the survival data (Sgrillo, 1982). The estimates of the parameters of shape (â) and scale (b) were done through the minimum square method, after the linearization of the Weibull model (Sgrillo, 1982), where â showed the curve type being $\hat{a}>1=$ type $\mathrm{I}$, mortality rate increased with time; $\hat{a} \cong 1=$ type II, mortality rate was constant; $\hat{a}<1=$ type III, mortality rate decreased with time. The mean 
longevity was estimated through the $\hat{a}$ and $b$ parameters generated and analyzed through the MOBAE statistical program (Haddad et al., 1995).

\section{RESULTS AND DISCUSSION}

The results showed that the parasitism rhythm was significantly different among the tested temperatures. The mean parasitism in the first $24 \mathrm{~h}$ was $60.90,81.65,121.05,117.55$, and 108.55 parasitized eggs at $15,20,25,28$, and $31^{\circ} \mathrm{C}$, respectively (Fig. 1). The highest tested temperature was inappropriate to $T$. remus development, since female adults had reduced longevity to just $1.7 \pm 0.02$ days (Table 1 ), and also, there was no adult emergence from parasitized
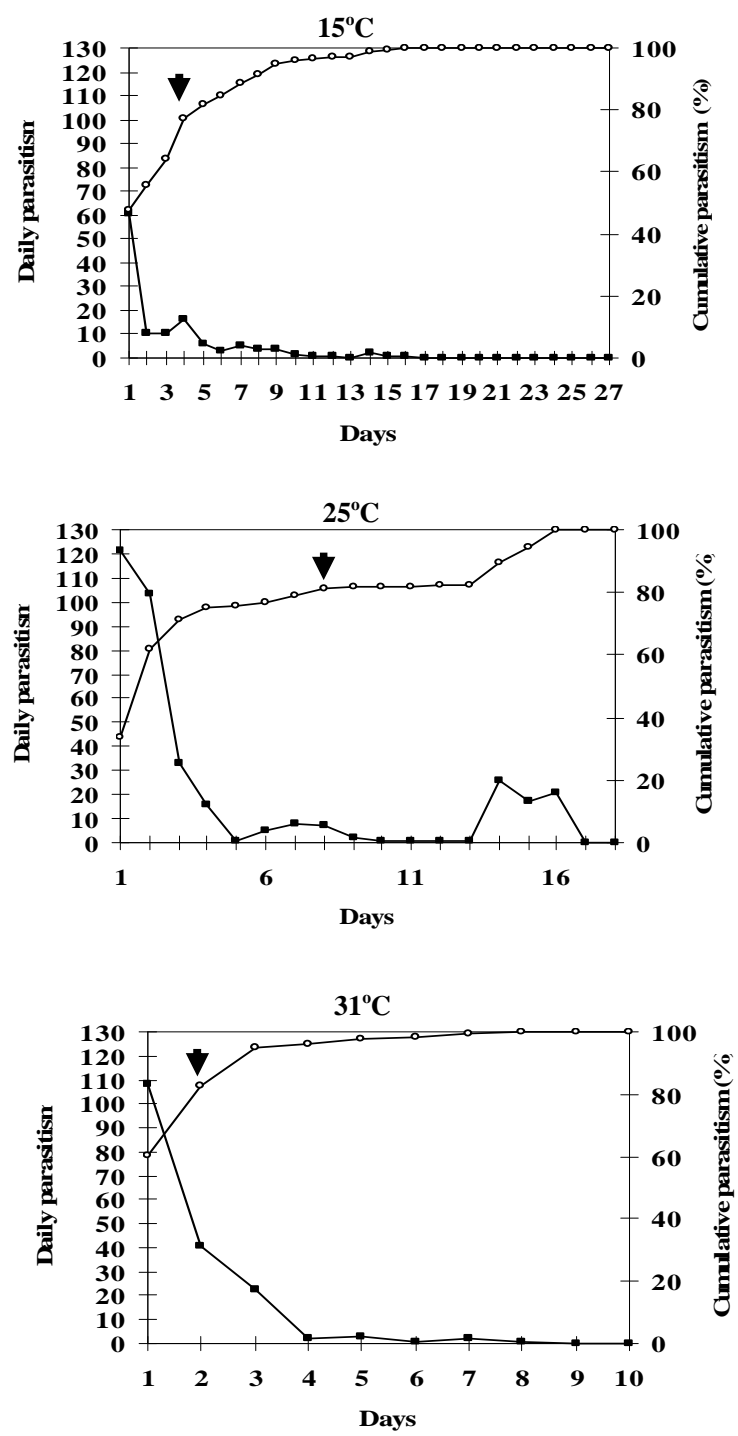

eggs. The female of $T$. remus reduced the number of eggs daily laid (daily parasitism) according to the time, the female was exposed to the specific treatment (Fig. 1). Therefore, it was clearly shown that parasitism decreased with time. The greater parasitism on the first days was shown at 15, 25, 28 and $31^{\circ} \mathrm{C}$, but at $20^{\circ} \mathrm{C}$ parasitoids had similar parasitism capacity through the whole adult lifespan (Fig. 1). The total number of S. frugiperda eggs parasitized was statistically similar at 25 and $28^{\circ} \mathrm{C}$, and 28 and $31^{\circ} \mathrm{C}$ (Table 1). The highest parasitism was reached at $20^{\circ} \mathrm{C}$, being statistically different from the other temperatures (Table 1). The lowest $T$. remus parasitism occurred at $15^{\circ} \mathrm{C}$ (Table 1), being this the worst temperature for $T$. remus.
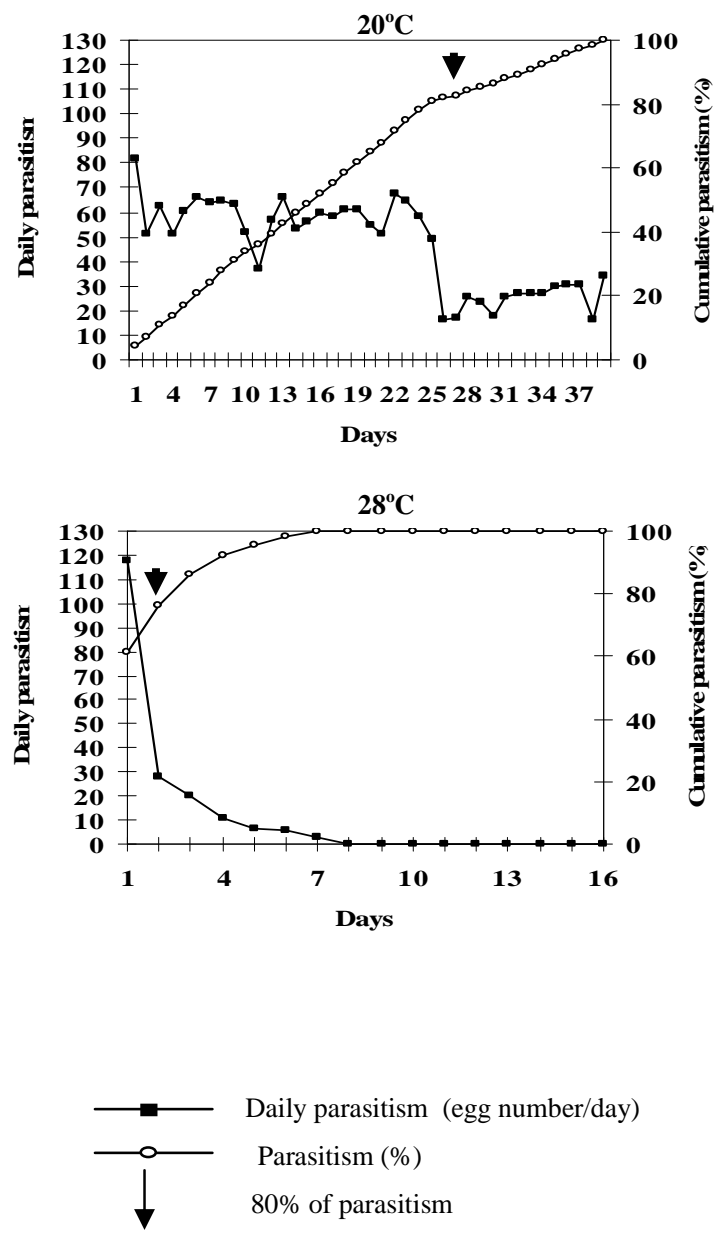

Figure 1 - Telenomus remus cumulative and daily parasitism on Spodoptera frugiperda eggs at different temperatures. RH: $70 \pm 10 \%$ and $12 \mathrm{~h}$ (L:D). 
Table 1 - Biological parameters $( \pm$ SEM) of Telenomus remus on Spodoptera frugiperda eggs at different temperatures (RH: $70 \pm 10 \%$ and $12 \mathrm{~h} \mathrm{L:D)}$.

\begin{tabular}{crlrl}
\hline Temperature $\left({ }^{\circ} \mathbf{C}\right)$ & Total number of parasitized eggs/female & \multicolumn{2}{c}{ Female longevity (days) } \\
\hline 15 & $9.28 \pm 1.23$ & $\mathrm{~d}$ & $15.5 \pm 0.30$ & $\mathrm{a}$ \\
20 & $58.73 \pm 8.85$ & $\mathrm{a}$ & $19.4 \pm 0.61$ & $\mathrm{a}$ \\
25 & $35.74 \pm 2.67$ & $\mathrm{~b}$ & $9.55 \pm 0.19$ & $\mathrm{~b}$ \\
28 & $27.56 \pm 1.80$ & $\mathrm{bc}$ & $7.65 \pm 0.13$ & $\mathrm{~b}$ \\
31 & $27.10 \pm 1.82$ & $\mathrm{c}$ & $7.7 \pm 0.39$ & $\mathrm{~b}$ \\
35 & $0.0 \pm 0.00$ & $\mathrm{e}$ & $1.7 \pm 0.02$ & $\mathrm{c}$ \\
\hline
\end{tabular}

Mean \pm SEM followed by the same letter within the column is not statistically different among themselves $(\mathrm{P}>0.05)(\mathrm{n}=20)$.

The highest parasitism at the first $48 \mathrm{~h}$ was reached at $25^{\circ} \mathrm{C}$, although, the highest total parasitism was observed at $20^{\circ} \mathrm{C}$ (Fig. 2). The temperatures of 28 and $31^{\circ} \mathrm{C}$ also had higher parasitism than $20^{\circ} \mathrm{C}$ at the first $24 \mathrm{~h}$ decreasing after the second day of parasitism (Fig. 2). Therefore, even though parasitism was higher in the first $24 \mathrm{~h}$ at 25,28 , and $31^{\circ} \mathrm{C}$, the best parasitism performance of $T$. remus was reached at $20^{\circ} \mathrm{C}$ due to the highest total parasitism rate.
However, T. remus at $20^{\circ} \mathrm{C}$ just reached $80 \%$ parasitism on the $27^{\text {th }}$ day after the parasitoid emergence what might compromise the control success in field conditions because 27 days was probably too much time for the plant to tolerate the pest attack. Therefore, the best performance obtained by $T$. remus female at $20^{\circ} \mathrm{C}$ was due to the longest longevity of adults at this temperature and that might be useful at laboratory conditions to better control the insect lifestock production.

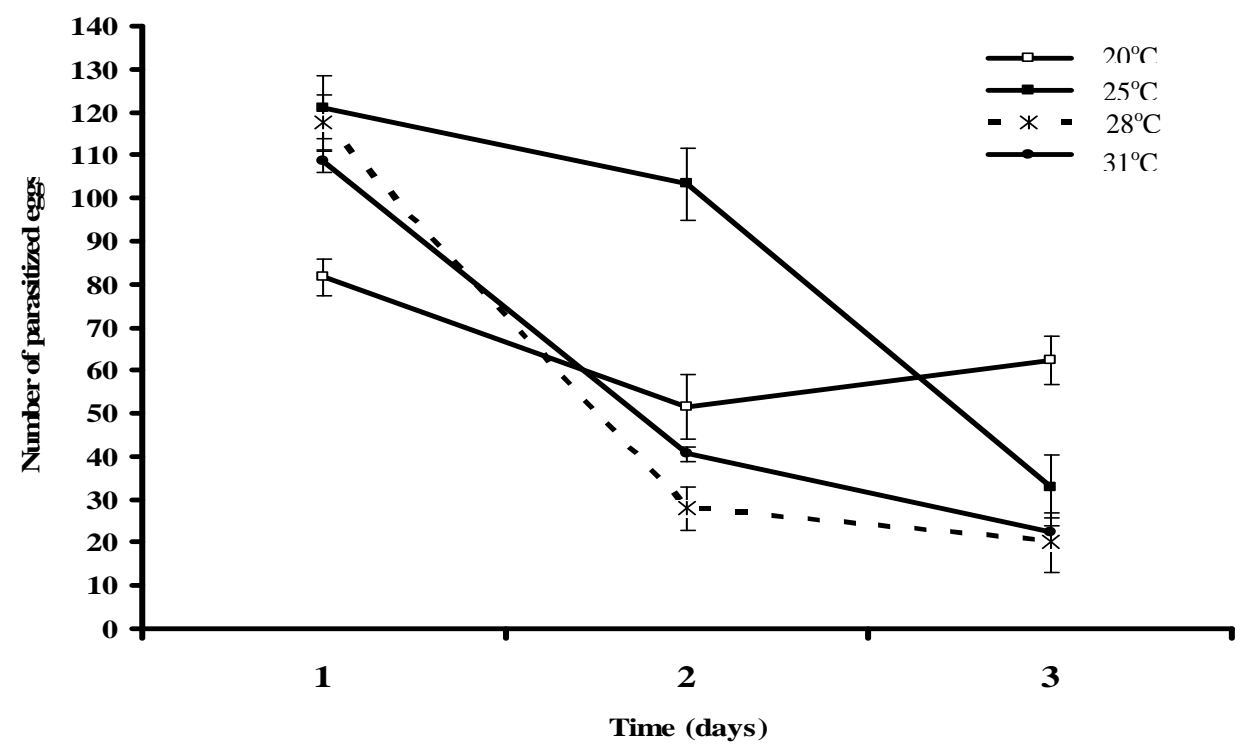

Figure 2 - Number of Spodoptera frugiperda parasitized eggs by Telenomus remus at temperatures of $20,25,28$, and $31^{\circ} \mathrm{C}$, at the first $72 \mathrm{~h}$ ( 3 days).

Adults kept at lower temperatures lived longer because of the lower metabolic activity of insects as a consequence of lowering temperatures (Gerling, 1972). This decrease in metabolic activity leads to a lower energy spending, which seems to prolong the laying period and consequently increasing total parasitism.
Temperatures of 15 and $35^{\circ} \mathrm{C}$ were probably close to fatal minimum and maximum temperatures what explained the lowest parasitism capacity observed for $15^{\circ} \mathrm{C}$ and no parasitism capacity at $35^{\circ} \mathrm{C}$.

T. remus had parasitism greater than $80 \%$ at 15 , $20,25,28$ and $31^{\circ} \mathrm{C}$ at day $5,27,8,2$, and 2 , 
respectively (Fig. 1). A value of $80 \%$ control is generally accepted as good control percentage and it is used to discuss the parasitoid efficacy (Zago et al. 2007). Mean longevity of T. remus female was inversely proportional to temperature (Table 1). The results showed longer longevity at 15 and $20^{\circ} \mathrm{C}$. At temperatures higher than $20^{\circ} \mathrm{C}, T$. remus had the longevity decreased, and $T$. remus longevity at 25,28 , and $31^{\circ} \mathrm{C}$ did not differ statistically among themselves. At $35^{\circ} \mathrm{C}$, the results showed the lowest longevity where adults just lived 1.7 days (Table 1).
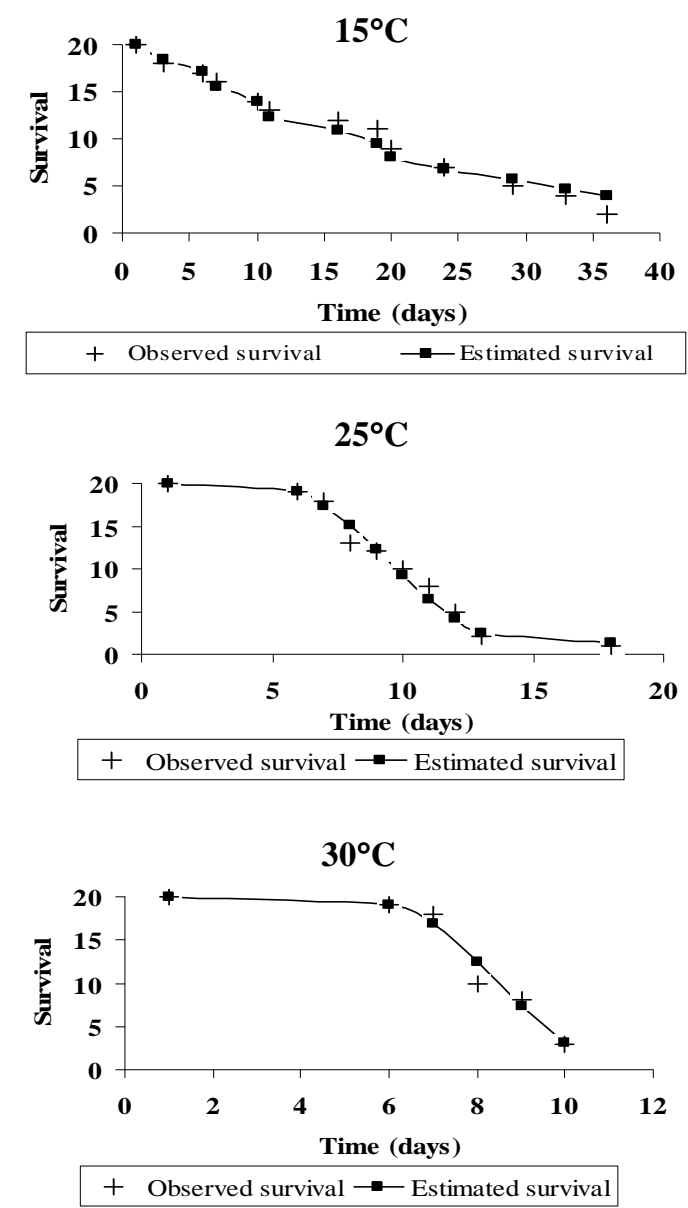

Figure 3 - Telenomus remus adult survival on Spodoptera frugiperda eggs at different temperatures. Values observed and estimated by the equation of Weilbull. UR: $70 \pm 10 \%$ and $12 \mathrm{~h}(\mathrm{~L}: \mathrm{D})$.

Similar results have been reported by other authors studying different parasitoids (Pratissoli et al., 2005). These results suggested that the biological control might be impaired somehow or at least had shorten its duration in Integrated Pest Management
The study of $T$. remus survival showed differences among the curves at different temperatures (Fig. 3). However, all the T. remus survival curves were from type I. This showed that for all temperatures, there was an increase in mortality during the time (â>1) (Fig. 3). It was possible to estimate the mean longevity of the population at different temperatures from the estimative of shape (â) and scale (b) and all data were fit into the Weilbull distribution for all the tested temperatures (Fig. 3). The survival curves showed that there was an increase in mortality through the time at higher temperatures.
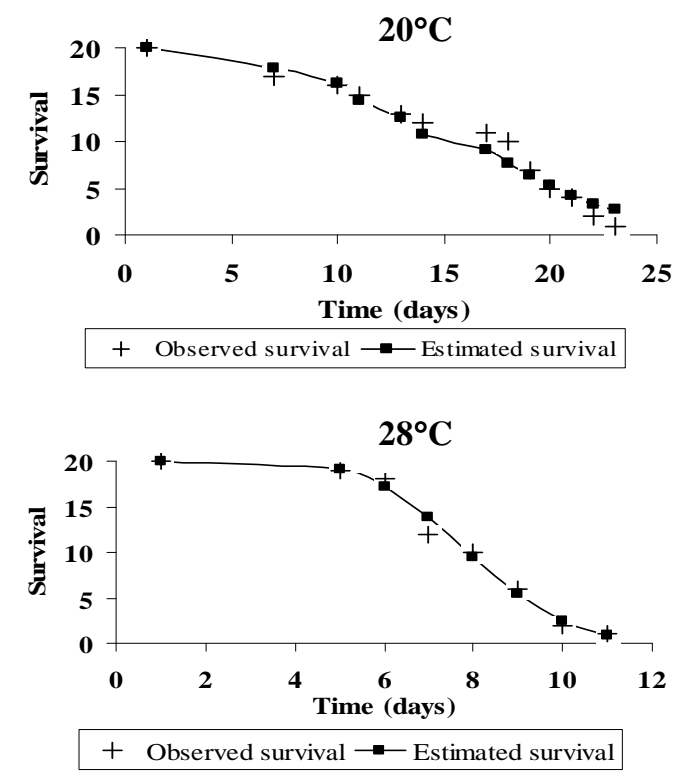

(IPM) programs carried out at warm weather places. This leads to a necessity of increasing parasitoid release frequency since they have higher temperatures. However, it is important to consider that $31^{\circ} \mathrm{C}$ or even warmer temperatures that might 
be reached in the field during the day are normally cooler during the night. Thus, future studies should be carried out evaluating the biology of the parasitoids exposed at variable temperatures and also different $T$. remus strains, better adapted to local temperatures might be tested before a field control program begins. Then, even though the best temperature for biological control using $T$. remus was identified as $20^{\circ} \mathrm{C}$, it could be strongly suggested to have a parasitoid releasing number based on the worst case scenario of temperatures what would ensure a better changes for the success of $T$. remus releasing.

The results showed that in general, $T$. remus might be an efficient parasitoid to be used to manage $S$. frugiperda outbreaks. T. remus has been shown to be more efficient than other parasitoids such as Trichogramma spp, for example, mainly because T. remus was able to parasitize the lower layers of the eggs masses (Cruz and Figueiredo, 1994) where Trichogramma spp were not able to reach due to its smaller size for example (Oliveira, 2005). Under field conditions, S. frugiperda might lay eggs in a single layer what might help to increase Trichogramma spp perfomance but this might also help $T$. remus performance. These possibilities still need to be tested.

In conclusion, it is important to point out that temperature is a very important factor to determine the success or failure of biological control (Maceda et al. 2003) but it is not the only issue. Photoperiod, relative humidity among other features play also a important role in the ecosystem and is crucial for the success of any biological control agent (Pratissoli, 1995; Cave, 2000). Other important point that must be considered is that at higher temperatures, the corium of eggs losses water what might lead to a decrease of $T$. remus capacity of parasitism (Fagundes, 2003).

The temperature influence on the $T$. remus parasitism capacity was also described by Gupta and Pawar (1985) who reported higher parasitism on eggs of Spodoptera litura by $T$. remus at temperatures from 25 to $30^{\circ} \mathrm{C}$. Similar results were also reported by Gautam (1986) that showed $27^{\circ} \mathrm{C}$ as the best temperature for T. remus parasitism on S. litura eggs.

In conclusion, T. remus could be a potential species for biological control that might be used in IPM programs conducted at areas of average temperature, similar to the most favorable temperature for its performance $\left(20\right.$ to $\left.25^{\circ} \mathrm{C}\right)$.
Also, it is important to point out that other studies addressing the ideal number of parasitoids to be released, the releasing interval, and also the dispersion capacity of $T$. remus still need to be conducted in order to have a complete recommendation of $T$. remus use in agriculture to be offered to growers.

\section{RESUMO}

Este trabalho estudou a capacidade de parasitismo de Telenomus remus Nixon (Hymenoptera: Scelionidae) em ovos de Spodoptera frugiperda (Smith) (Hymenoptera: Scelionidae) nas temperaturas de $15,20,25,28,31$ e $35^{\circ} \mathrm{C}$ objetivando usar esse inimigo natural em programas de controle biológico em culturas onde S. frugiperda é considerada praga. O parasitismo ocorrido nas primeiras $24 \mathrm{~h}$ foi de 60,$90 ; 81,65$; 121,$05 ; 117,55$ e 108,55 ovos parasitados por fêmea em massas ovos com aproximadamente 150 ovos, nas temperaturas de $15,20,25,28$ e $31^{\circ} \mathrm{C}$. Fêmeas de T. remus causaram mais de $80 \%$ do parasitismo dos ovos nas temperaturas de 15, 20, 25,28 e $31^{\circ} \mathrm{C}$ aos 5, 27, 8, 2 e 2 dias, respectivamente. $\mathrm{Na}$ temperatura de $35^{\circ} \mathrm{C}$ não houve parasitismo. As maiores taxas de parasitismo ocorreram nas temperaturas de 20, 25, 28 e $31^{\circ} \mathrm{C}$. A longevidade média de fêmeas de $T$. remus nas temperaturas compreendidas entre $15 \mathrm{e}$ $31^{\circ} \mathrm{C}$ variou de 15,5 a 7,7 dias. A temperatura máxima testada $\left(35^{\circ} \mathrm{C}\right)$ foi inadequada ao desenvolvimento de $T$. remus, sendo que nessa temperatura as fêmeas apresentaram longevidade bastante reduzida $(1,7 \pm 0,02$ dia) e não houve emergência de adultos. Todas as curvas de sobrevivência para T. remus foram do tipo I o que mostram que para todas as temperaturas há um aumento da taxa de mortalidade com o tempo.

\section{REFERENCES}

Bleicher, E. and Parra, J.R.P. (1990), Espécies de Trichogramma parasitóides de Alabamma argilacea. II. Tabela de vida de fertilidade e parasitismo de três populações. Pesquisa Agropecuária Brasileira, 25, 207-214.

Cave, R.D. (2000), Biology, ecology and use in pest management of Telenomus remus. Biocontrol News and Information, 21, 21-26. 2000. 
Cruz, I. (1995), A lagarta-do-cartucho na cultura do milho. Sete Lagoas, EMBRAPA-CNPMS. 45p. (Circular Técnica 21).

Diez-Rodriguez, G.I.; Omoto, C. (2001), Herança da resistência de Spodoptera frugiperda (J.E. Smith) (Lepidoptera : Noctuidae) à lambda-cialotrina. Neotropical Entomology, 30, 311-316.

Fagundes, F.P. (2003), Biologia e exigências térmicas de Trichogramma pretiosum Riley, 1879 e $T$. exiguum Pinto and Platner, 1978 (Hymenoptera: Trichogrammatidae) criados em ovos de Plutella Xylostella (L.,1758) (Lepidoptera: Plutellidae) visando ao seu zoneamento ecológico, $74 \mathrm{f}$. Dissertação de Mestrado, Universidade Federal Rural do Recife, Recife.

Ferrer, F. (2001), Biological control of agricultural insect pests in Venezuela; advances, achievements, and future perspectives. Biocontrol News and Information, 22, 67-74.

Figueiredo, M.L.C.; Cruz, I.; Della Lucia, T.M.C. (1999), Controle integrado de Spodoptera frugiperda (Smith and Abbott) utilizando-se o parasitóide Telenomus remus Nixon. Pesquisa Agropecuária Brasileira, 34, 1975-1982.

Figueiredo, M.L.C.; Della Lucia, T.M.C.; Cruz, I. (2002), Effect of Telenomus remus Nixon (Hymenoptera: Scelionidae) density on control of Spodoptera frugiperda (Smith) (Lepidoptera: Noctuidae) egg masses upon release in maize field. Revista Brasileira de Milho e Sorgo, 1, 12-19.

Fuentes, S.F. (1994), Produccion y uso de Trichogramma como regulador de plagas. Lima, Red de acción em alternativas al uso de agroquímicos (RAAA), 192p.

Gautam, R.D. (1986), Effect of different temperatures and relative humidities on the efficiency of parasitoid, Telenomus remus Nixon (Scelionidae: Hymenoptera) in the laboratory. Journal of Entomological Research, 10, 34-39. 1986.

Gerling, D. (1972), The developmental biology of Telenomus remus Nixon (Hym.: Scelionidae). Bulletin of Entomological Research, 61, 385-488.

Gupta, M.; Pawar, A.D. (1985), Multiplication of Telenomus remus Nixon on Spodoptera litura (Fabricius) reared on artificial diet. Journal of Advanced Zoology. 6, 13-17.

Haddad, M.L., R.C.B. Moraes; J.R.P. Parra. (1995), MOBAE, Modelos Bioestatísticos Aplicados à Entomologia. Manual. ESALQ/USP. 44p.

Hernández, D.; Díaz, F. (1996), Efecto de la temperatura sobre el desarrollo de Telenomus remus Nixon (Hymenoptera: Scelionidae) parasitoide de Spodoptera frugiperda (Smith) (Lepidoptera: Noctuidae). Boletin de Entomologia Venezolana, 11, 149-153.
Hernández, D.; Ferrer, F.; Linares, B. (1989), Introducion de Telenomus remus Nixon (Hym.: Scelionidae) para controlar Spodoptera frugiperda (Lep.: Noctuidae) en Yaritagua-Venezuela. Agronomía Tropical, 39,199-205.

Kasten Jr, A.A.; Precetti, C.M.; Parra, J.R.P. (1978), Dados biológicos comparativos de Spodoptera frugiperda em duas dietas artificiais e substrato natural. Revista de Agricultura, 53, 68-78.

Maceda, A.; Hohmann, C.L.; Santos, H. R. (2003), Temperature effects on Trichogramma pretiosum Riley and Trichogramma annulata De santis. Brazilian Archives of Biology and Technology, 46, 27-32.

Morales, J.S.; Gallardo, J.S.; Vásquez, C.; Rios, Y. (2001), Respuesta funcional de Telenomus remus (Hymenoptera: Scelionidae) a los huevos de Spodoptera frugiperda (Lepidoptera: Noctuidae). Bioagro, 13, 49-55.

Noldus, L.P.J.J. (1989), Semiochemicals foraging behaviour and quality of entomophagous insects for biological control. Journal Applied of Entomology, 108, 425-451.

Pratissoli, D. (1995), Bioecologia de Trichogramma pretiosum Riley, 1879, nas traças, Scrobipalpuloides absoluta (Meyrick, 1917) e Phthorimaea operculella (Zeller, 1873), em tomateiro. Tese de Doutorado, ESALQ/USP, Piracicaba,135p.

Pratissoli, D.; Zanuncio, J. C.; Vianna, U. R.; Andrade, J. S.; Zanotti L. C. M.; Silva, A. F. Biological Characteristics of Trichogramma pretiosum and Trichogramma acacioi (Hym.: Trichogrammatidae), Parasitoids of The Avocado Defoliator Nipteria panacea (Lep.: Geometridae), on Eggs of Anagasta kuehniella (Lep.: Pyralidae). Brazilian Archives of Biology and Technology, 48, 7-13.

Schwartz, A.; Gerling, D. (1974), Adult biology of Telenomus remus (Hymenoptera: Scelionidae) under laboratory conditions. Entomophaga,19,482-492.

Sgrillo, R.B. (1982), A distribuição de Weibull como modelo de sobrevivência de insetos. Ecossistema, 7, 9-13.

Zago, H.B.; Pratissoli, D. P.; Barros, R.; Gondim Jr, M.G.C.; Santos Jr, H.J.G. (2007), Capacidade de Parasitismo de Trichogramma pratissolii Querino and Zucchi (Hymenoptera: Trichogrammatidae) em Hospedeiros Alternativos, Sob Diferentes Temperaturas. Neotropical Entomology, 36, 84-89. 